\title{
Efficacy of different fungicides and biopesticides for the management of lentil wilt (fusarium oxysporum f. sp. lentis)
}

\author{
${\text { KAMLESH } \text { RAM }^{1 *} \text { AND RAMESH SINGH }}^{2}$
}

\begin{abstract}
In Vitro and In Vivo studies on the efficacy of fungicides and biopesticides was done on Fusariumoxysporum f. sp. lentis. Among the fungicides, Carbedazim was the most effective as they have completely inhibited mycelia growth of the test fungus. Benomyl, Topsin - M, Ridomil,Vltavax were found the next best in inhibiting the mycelial growth of the pathogen up to $92.11 \%$ to $83.46 \%$ respectively under In Vitro and In Vivo condition. In case of biopesticides, Sadabahar was least effective plant extracts which causes $42 \mathrm{~mm}$ of radial growth and inhibited the growth of the only $19.23 \%$ under In Vitro condition. Seed treatment with Carbendazim $(0.2 \%)$ under In Vitro and In Vivocondition, produced maximum seed germination $(95.50 \%$ and $95.33 \%)$, minimum wilt incidence $(5.16 \%$ and $3.65 \%)$ and highest grain yield $(10.50 \mathrm{q} / \mathrm{ha}$ and $10.35 \mathrm{q} / \mathrm{ha}$ ). Among the test plant extracts Tulsi was least effective, and show the minimum seed germination $(80.00 \%$ and $77.50 \%)$, maximum wilt incidence $(15.70 \%$ and $14.10 \%)$, and lowest grain yield ( $3.92 \mathrm{q} / \mathrm{ha}$ and $4.17 \mathrm{q} / \mathrm{ha})$, under In Vitro and In Vivo condition, respectivly.
\end{abstract}

\section{KEYWORDS}

Key words: Lentil, wilt, Fungicides and biopesticides

\begin{tabular}{llc}
\multicolumn{2}{c}{ ARTICLE INFO } \\
\hline Received on & $:$ & $09 / 11 / 2020$ \\
Accepted on & $:$ & $23 / 01 / 2021$ \\
Published online & $:$ & $19 / 03 / 2021$ \\
\hline
\end{tabular}

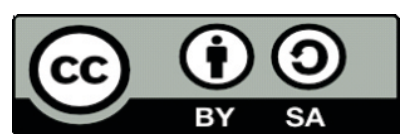

\section{INTRODUCTION}

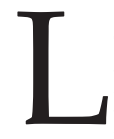

entil (Lens culinaris Medikus) is a high value cool session pulse crop and containing average about 28.3 per cent protein in its dry seed (Singh and Bhatt, 2015). The crop is acheap source of protein compared to animal protein. Lentil play a significant role in human, animal nutrition and soil fertility improvement (Singh and Bhatt, 2013). The crop suffers from a several diseases among the fungal pathogen of lentil wilt caused by Fusarium oxysporum f.sp. lentis (Singh et al.,2014) is major threat to the lentil cultivation in the world. It play a major role in reducing lentil yield and caused severe damage at all stages of plant growth, with more incidence in flowering and pod filling stage than early vegetative stage (Chavdarov, 2006). The wilt appeared in field within three to four week after sowing under favorable condition, the wilt infection can damage the crop yield, and vascular wilt considerable important disease in India causing more than 50 per cent loss in some field (Khare, 1981 and Vasudeva and Srinivason, 1952). It therefore, need a constant watch and effect to evolve new fungicides and biopesticides are using for controlling the diseases (Jamil and Kumar, 2010). The present study is carried out to evaluate different group of fungicides and biopesticides against lentil wilt and their effect on seed germination, disease development and yield also.

\section{MATERIAL AND METHODS}

\section{Efficacy of different fungicides}

Seven fungicides Viz., Carbendazim, Benomyle, Topsin-M, Ridomil, Vitavax, Chlorothalonil and Zineb and one antibiotics

\footnotetext{
Deptt. of Plant Pathology, Brahmanand Post Graduate College, Rath, Hamirpur, Uttar Pradesh, India

${ }^{2}$ Deptt. of Plant Pathology, Tilak DharI Post Graduate College Jaunpur Uttar Pradesh, India

*Corresponding author email : kamleshram.rath@gmail.com
}

streptomycin were assessed for their efficacy against Fusarium oxysporum f. sp. lentis through laboratory bio- assay using poison food technique (Nane and Thapliyal, 1993). Requisite quantities of fungicides were incorporated in two per cent potato dextrose agar medium. About $15 \mathrm{ml}$ of melted media PDA was poured in each sterilized petri plate and allowed to solidify. These petri plates were inoculated by test fungus separately (Fig.1). A circular $5 \mathrm{~mm}$ disc of one-week old culture of pathogen was cut with a sterilized cork borer, lifted and transferred aseptically in the center of petri plate containing the medium with test fungicides. The control plates were kept where the culture disc was grown in same condition on PDA without fungicides. Each treatment was replicated three times. Treated plates were incubated at room temperature $\left(25 \pm 2^{\circ} \mathrm{C}\right)$ for a period of seven days. Colony diameter was recorded in $\mathrm{mm}$ and per cent of mycelium growth inhibition was calculated by using the formula (Eq.1) given by (Vincent, 1927). $\mathrm{PI}=\frac{\mathrm{C}-\mathrm{T}}{\mathrm{C}} \mathrm{-} \times 100[\mathrm{Eq} .1$ ]
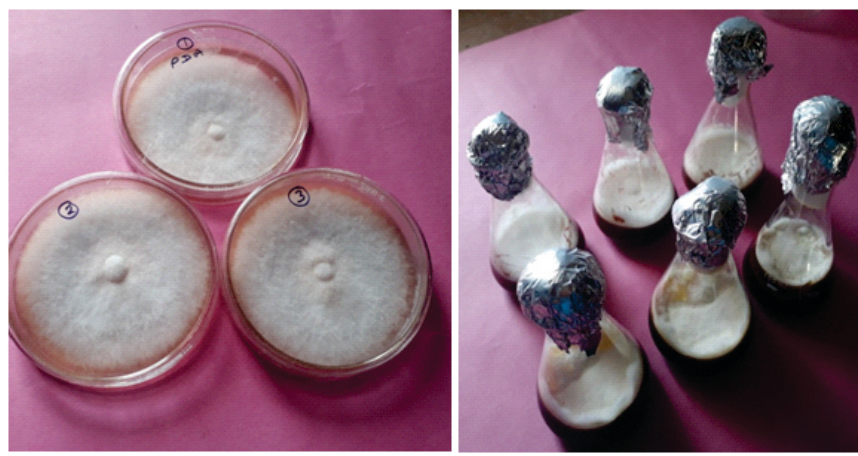

Fig. 1: Fusarium oxysporum f.sp. lentis isolates and mass culturing 
Where,

PI $=$ Per cent inhibition

$\mathrm{C}=$ Colony diameter $(\mathrm{mm})$ control

$\mathrm{T}=$ Colony diameter $(\mathrm{mm})$ in treatment

\section{Efficacy of different plant extracts}

In order to find out the efficacy of various plant extracts against the Fusarium wilt of lentil, four plant extracts Viz., leaves of Neem,Tulsi, Madar and Sadabahar were used. Fresh leaves were collected and washed thoroughly in distilled water. Hundred gm of each washed plant material was grinded in pestle mortar by adding equal amount $(100 \mathrm{ml})$ of sterilized distilled water $(1: 1 \mathrm{v} / \mathrm{w})$ and heated at $80^{\circ} \mathrm{C}$ or 10 minutes in hot water both. The material was filtered through double layered muslin cloth and centrifuged at 1000rpm for 10 minutes. The supernatant was collected and filtered through What man paper no.1 filter paper and treated as standard plant extract (100\%). $10 \mathrm{ml}$ of stock solution of extract was incorporated in $90 \mathrm{ml}$ medium to make 10 per cent concentration of the extract. $15 \mathrm{ml}$ melted PDA was poured in sterilized petri plates. After solidification all the plates were inoculated individually with $5 \mathrm{~mm}$ diameter culture disc of Fusarium oxysporum f. sp. lentis. PDA plates without plant extracts but inoculated with Fusarium oxysporum f. sp. lentis served as control. Three times were maintained for all the treatments and plates were incubated at $25 \pm 2^{\circ} \mathrm{C}$. Colony diameter was measured in $\mathrm{mm}$ (Fig.2) and percent of mycelium growth inhibition was calculated by using equation 1.

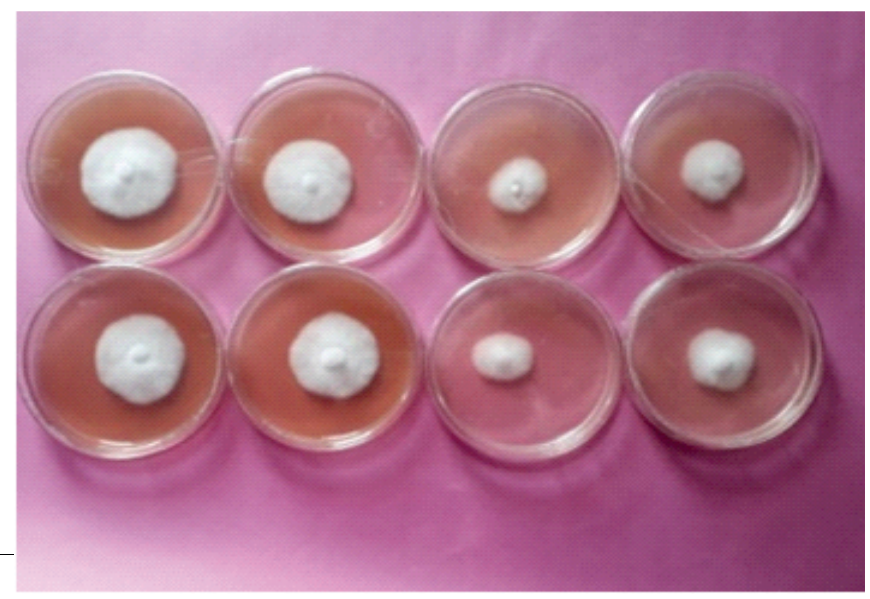

Fig.2: Effect of biopesticides against Fusarium oxysporum f. sp. lentis

\section{Efficacy of fungitoxicants under field condition}

Three fungicides, one antibiotic and two plant extracts Viz., Carbendazim, Benomyl, Steptomycin, Chlorothalonil, Neem and Tulsi were used for seed treatment. Seeds were treated with fungitoxicant before sowing and dried properly. Found effective in bio assay test trails of natural condition with same sets of treatments for two crop seasons (2018-19 and 2019-20). The experiment was laid out in RBD with three replications at Students Research Farm of BNPG College, Rath, Hamirpur.The observation on the seed germination, wilt incidence and yield wererecorded. Wilt incidence was calculated using following formula:
Disease incidence $\%=\frac{\text { Total number of wilted plants }}{\text { Total plant population }} \times 100$

\section{RESULTS AND DISCUTION}

All the treatments were found significantly superior compared to the control (Table 1). Among the tested seven fungicides, Carbendazim is the most effective as they have inhibited the mycelia growth completely of the test fungus (Fig. 3), whereas Benomyl, Topsin - M, Ridomil and Vitavax were found the next best in inhibiting the mycelial growth of the pathogen up to $92.11 \%$ to $83.46 \%$, those were statistically at par with each other. Sadabahar was least effective plant extracts which causes $42 \mathrm{~mm}$ of radial growth and inhibited the growth of only $19.23 \%$ (Fig. 4).

Table 1: Efficacy of fungicides and biopesticides on the growth of the pathogen in vitro

\begin{tabular}{l|ccc}
\hline Treatments & Dose \%/ppm & $\begin{array}{c}\text { Radial } \\
\text { growth (mm) }\end{array}$ & $\begin{array}{c}\text { Percent } \\
\text { inhibition }\end{array}$ \\
\hline Carbendazm & $0.2 \%$ & 0.00 & 0.00 \\
Benomyl & $0.2 \%$ & 4.10 & 92.11 \\
Topsin -M & $0.2 \%$ & 5.20 & 90.00 \\
Ridomil & $0.2 \%$ & 6.20 & 88.07 \\
Vitavax & $0.2 \%$ & 8.60 & 83.46 \\
Chlorothalonil & $0.2 \%$ & 18.20 & 65.00 \\
Zineb & $0.2 \%$ & 24.00 & 53.84 \\
Neem & $10 \%$ & 25.00 & 51.92 \\
Streptomycin & $500 p p m$ & 31.25 & 39.90 \\
Tulsi & $! 0 \%$ & 38.00 & 26.92 \\
Madar & $10 \%$ & 41.00 & 21.15 \\
Sadabahar & $10 \%$ & 42.00 & 19.23 \\
Control & - & 52.00 & - \\
CD at 5\% & - & 3.17 & - \\
SEm & - & 1.08 & - \\
\hline
\end{tabular}

The result obtained from Table 2, showed that all the treatments were significantly effective in reducing wilt percentage over control.

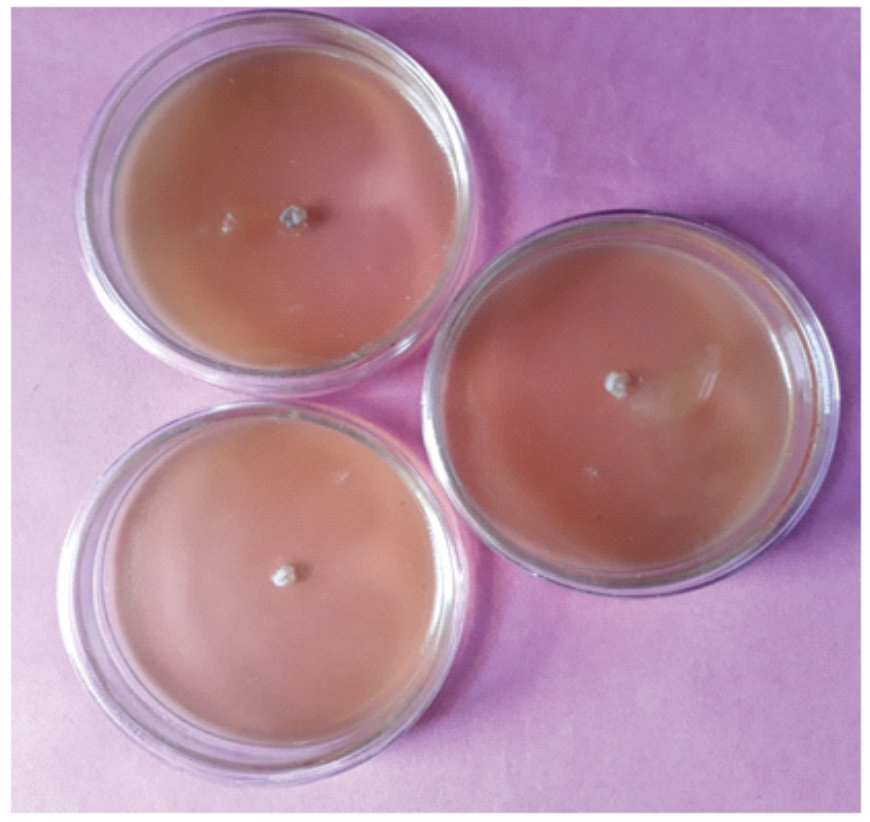

Fig. 3: Check the fungus growth by using carbendazim 
Table2: Efficacy of seed treatment with fungicides and biopesticides on seed germination, wilt incidence and yield of lentil

\begin{tabular}{|c|c|c|c|c|c|c|c|}
\hline \multirow{2}{*}{ Treatment } & \multirow{2}{*}{$\begin{array}{l}\text { Dose } \\
\% / \text { ppm }\end{array}$} & \multicolumn{2}{|c|}{ Seed germination } & \multicolumn{2}{|c|}{ Wilt incidence } & \multicolumn{2}{|c|}{ Yield q/ha } \\
\hline & & $2018-19$ & $2019-20$ & $2018-19$ & $2019-20$ & $2018-19$ & $2019-20$ \\
\hline Carbendazim & $0.2 \%$ & $\begin{array}{c}95.33 \\
(77.48)^{*}\end{array}$ & $\begin{array}{c}95.50 \\
(77.77)\end{array}$ & $\begin{array}{c}5.16 \\
(13.12)\end{array}$ & $\begin{array}{c}3.65 \\
(10.98)\end{array}$ & $\begin{array}{c}10.35 \\
(18.75)\end{array}$ & $\begin{array}{c}10.50 \\
(18.89)\end{array}$ \\
\hline Benomyl & $0.2 \%$ & $\begin{array}{c}92.50 \\
(74.17)\end{array}$ & $\begin{array}{c}91.20 \\
(72.99)\end{array}$ & $\begin{array}{c}5.03 \\
(14.18)\end{array}$ & $\begin{array}{c}5.50 \\
(13.53)\end{array}$ & $\begin{array}{c}10.08 \\
(18.50)\end{array}$ & $\begin{array}{c}9.90 \\
(18.32)\end{array}$ \\
\hline Streotomycin & $500 \mathrm{ppm}$ & $\begin{array}{c}90.55 \\
(72.13)\end{array}$ & $\begin{array}{c}89.30 \\
(72.25)\end{array}$ & $\begin{array}{c}8.55 \\
(16.98)\end{array}$ & $\begin{array}{c}6.90 \\
(15.19)\end{array}$ & $\begin{array}{c}8.92 \\
(17.36)\end{array}$ & $\begin{array}{c}9.07 \\
(17.52)\end{array}$ \\
\hline Chlorothalonil & $0.2 \%$ & $\begin{array}{l}90.00 \\
(71.69)\end{array}$ & $\begin{array}{c}88.10 \\
(69.86)\end{array}$ & $\begin{array}{c}8.80 \\
(17.24)\end{array}$ & $\begin{array}{c}9.90 \\
(18.32)\end{array}$ & $\begin{array}{c}8.10 \\
(16.52)\end{array}$ & $\begin{array}{c}7.82 \\
(16.22)\end{array}$ \\
\hline Neem & $10 \%$ & $\begin{array}{l}85.11 \\
(67.29)\end{array}$ & $\begin{array}{c}82.30 \\
(65.15)\end{array}$ & $\begin{array}{c}10.20 \\
(18.60)\end{array}$ & $\begin{array}{c}12.30 \\
(20.51)\end{array}$ & $\begin{array}{c}6.50 \\
(14.75)\end{array}$ & $\begin{array}{c}5.85 \\
(13.96)\end{array}$ \\
\hline Tulsi & $10 \%$ & $\begin{array}{l}80.00 \\
(63.52)\end{array}$ & $\begin{array}{c}77.50 \\
(61.70)\end{array}$ & $\begin{array}{l}15.70 \\
(23.33)\end{array}$ & $\begin{array}{c}14.10 \\
(22.01)\end{array}$ & $\begin{array}{c}3.92 \\
(11.40)\end{array}$ & $\begin{array}{c}4.17 \\
(11.77)\end{array}$ \\
\hline Control & - & $\begin{array}{l}75.00 \\
(60.00)\end{array}$ & $\begin{array}{c}74.60 \\
(59.76)\end{array}$ & $\begin{array}{l}35.50 \\
(36.57)\end{array}$ & $\begin{array}{c}40.10 \\
(39.29)\end{array}$ & $\begin{array}{c}2.80 \\
(9.59)\end{array}$ & $\begin{array}{c}2.55 \\
(9.17)\end{array}$ \\
\hline $\begin{array}{l}\text { CD at } 5 \% \\
\text { SEm }\end{array}$ & & $\begin{array}{l}4.17 \\
1.30\end{array}$ & $\begin{array}{l}5.59 \\
1.75\end{array}$ & $\begin{array}{l}1.37 \\
0.43\end{array}$ & $\begin{array}{l}1.95 \\
0.61\end{array}$ & $\begin{array}{l}0.76 \\
0.23\end{array}$ & $\begin{array}{l}1.02 \\
0.32\end{array}$ \\
\hline
\end{tabular}

${ }^{*}$ Figure in parenthesis are angular transformed values

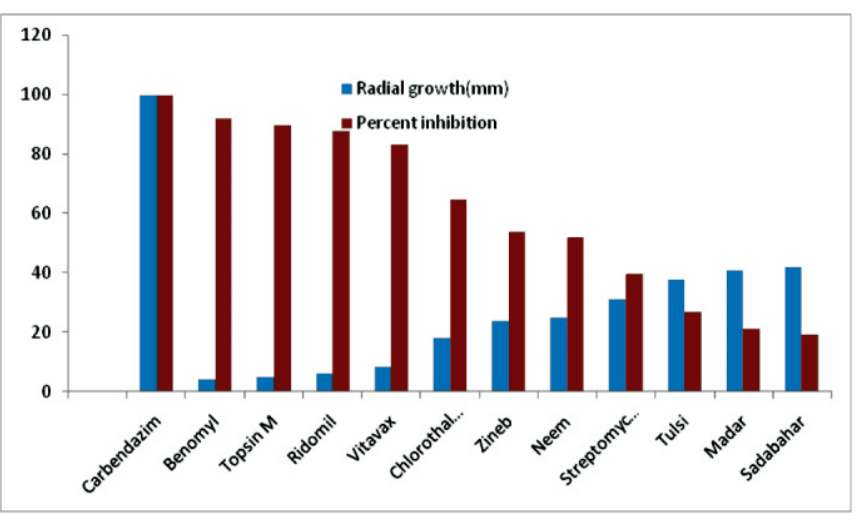

Fig. 4: Effect of fungicides and biopesticides against mycelia growth of Fusarium oxysporum f.sp.lentis

In the present study In Vitro condition among tested fungicides, only Carbendazim were most effective fungicides and completely inhibited the growth of the Fusarium oxysporum f. sp. lentis which is in close agreement with the finding of the Maheswari et al., (2008), against the wilt of lentil caused by Fusarium oxysporum f. sp. lentis, and same as result were also reported by Chanu et al., (2019)tested the different fungicides as inhibiting the mycelia growth of the Fusarium oxysporum f. sp.pisi.

The maximum seed germination $(95.50 \%$ and $95.33 \%)$, minimum wilt incidence $(5.16 \%$ and $3.65 \%$ ) and highest grain yield (10.50 q/ha and $10.35 \mathrm{q} / \mathrm{ha}$ ) was found seed treatment with Carbendazim (0.2\%). Next best effective fungicides Benomyl followed by Streptomycin and Chlorothalonil, were statistically at par with each other in respect to seed germination, wilt incidence and yield also. Among the test plant extracts Tulsi was tested effective, which show the minimum seed germination $(80.00 \%$ and $77.50 \%)$, maximum wilt incidence (15.70\% and $14.10 \%)$, and lowest grain yield (3.92 q/ha and $4.17 \mathrm{q} / \mathrm{ha}$ ) during both the years (Fig. 5).

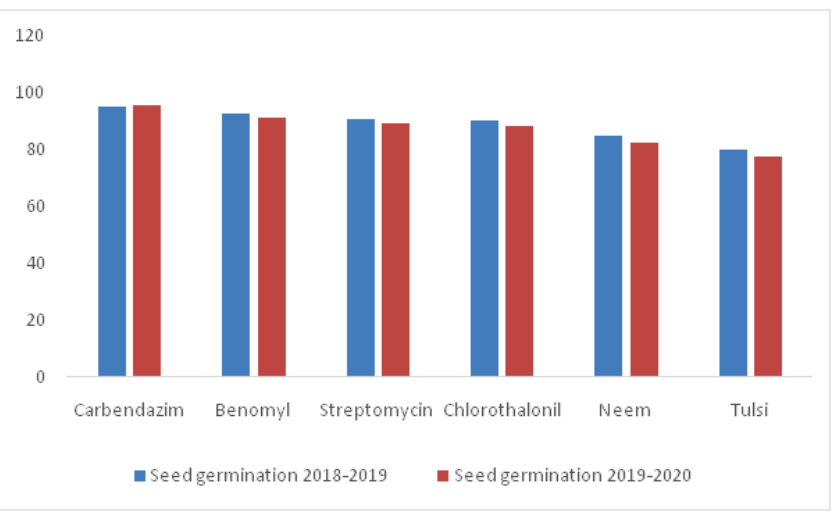

Fig. 5: Effect of fungicides and biopesticides of seed germination

In field condition the maximum seed germination, minimum wilt incidence and maximum grain yield was found seed treatment with Carbendazim (0.2\%) which is in close

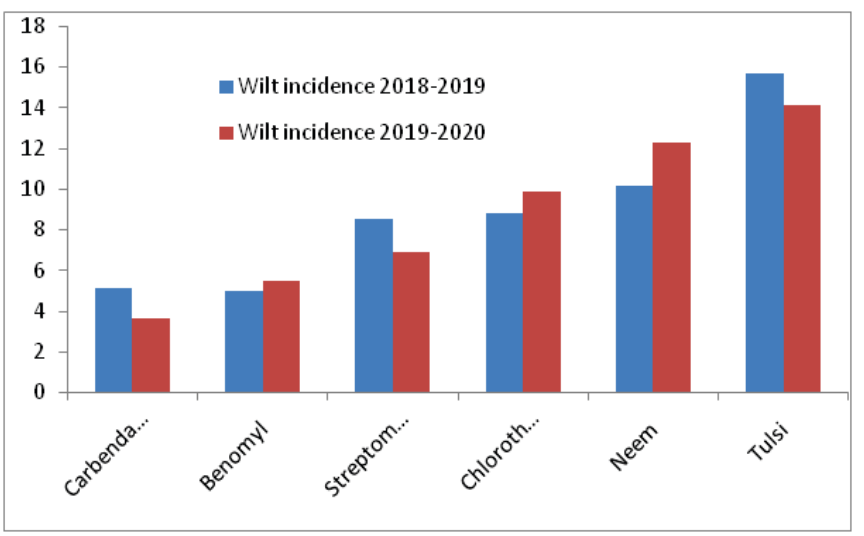

Fig. 6: Percent inhibition of wilt incidence 


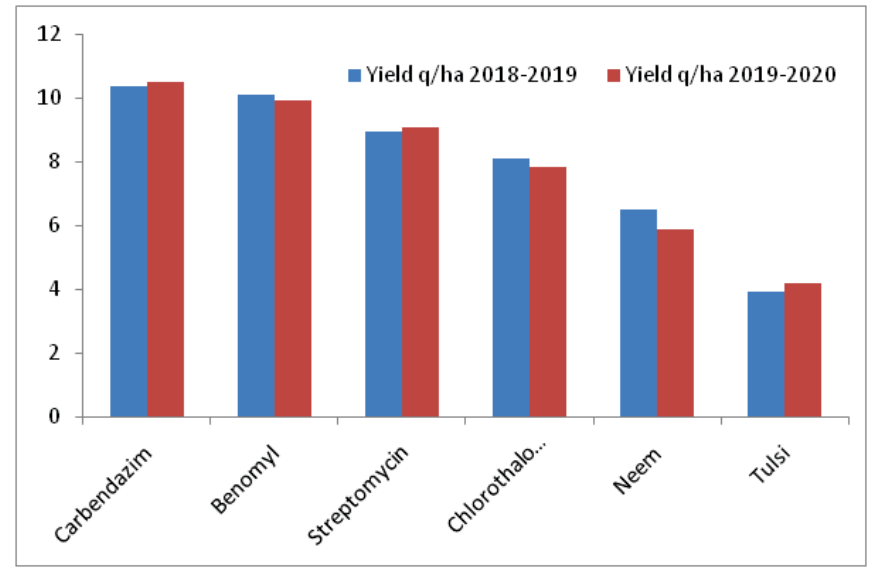

Fig. 7: Effect of fungicide and biopesticides on yield

agreement with the finding out Singh et al.(2010), against the wilt of lentil caused by Fusarium oxysporum f. sp. lentis, and similar result were also reported by Gupta et al. (1988) and Sugha et al. (1995) tested the different fungicides as seed

\section{REFERENCES}

Chanu WT, Sinha B, Sovita Devi PH, Ranjit Sharma PH and Singh NG. 2019. In vitro assessment of fungicides against Fusarium wilt of pea. Journal of Pharmacognosy and Phytochemistry 8: 24872490.

Chavdarov P and Stoilova T. 2006. Evaluation of lentil germplasm for disease resistance to Fusarium wilt. Journal of Central Europian Agriculture 7: 121-126.

Gupta RP and Singh DP. 1988. Seed treatment with Bavistin and Rhizobium and its effect on wilt incidence, nodulation and yield of chickpea. Pesticides Mumbai 22: 9-10.

Jamil S and Kumar M. 2010. Evaluation of fungicides against phyllosphere microflora of foliage plant. Biology foram, 2:5659.

Khare MN. 1981. In Diseases of Lentils, Eds: C Webb and G. Hawtin. Farnham Royal. UK: 1 CARDA / CAB. Pp. 163-172.

Maheshwari SK, Nazir AB, Masoodi SD and Beig MA. 2008. Chemical control of lentil wilt caused by Fusarium oxysporum f. sp. lentis. Ann. Pl. Protect. Sci.16: 419-421.

Nane YL and Thapliyal PN. 1993. Fungicides in Plant Disease Control. Oxford and IBH Publishing co. Pvt. Ltd. New Delhi, $3^{\text {rd }}$ Eds. Pp. $525-542$.

Ram K and Singh J.2008. Evaluation fungicides against Fusarium treatment against the wilt of chickpea caused by Fusarium oxysporum f. sp. ciceri, and Ram and Singh(2008) tested the different fungicides as seed treatment against the wilt of linseed caused by Fusarium oxysporum f. sp.lini.(Fig.6 and 7)

\section{CONCLUSION}

This experiment brings new way to the efficacy of different fungicides and biopesticides against the pathogen Fusarium oxysporum f. sp. lentis. Among the seven fungicides, carbendazim is the most effective as they have checked the mycelia growth of the test fungus whereas benomyl, topsin$\mathrm{M}$, ridomil and vitavax were found the next best inhibiting and sadabahar was least effective the mycelia growth of the test fungus. In field conditions the maximum seed germination and minimum wilt incidence and highest grain yield was found by seed treatment with carbendazim, followed by benomyle, streptomycin and chlorothalonil. Plant extract tulsi was least effective which show the minimum seed germination and maximum wilt incidence and lowest grain yield.

oxysporum f.sp lini, of linseed. Ann. of Pl. Protec. Sci.18: 411414.

Singh AK and Bhatt BP. 2015. Late sown lentil performance in response to foliar application of zinc. Bangladesh Journal of Botany 44(1):125-128.

Singh AK and Bhatt BP. 2013. Effects of foliar application of zinc on growth and seed yield of late-sown lentil. Indian J. Agril. Sci. 83 (6): 622-626.

Singh AK, Singh KM, Bharati RC, Chandra N, Bhatt BP and Pedapati A. 2014. Potential of Residual Sulphur and Zinc Nutrition in Improving Powdery Mildew (Erysiphe trifolii) Disease Tolerance of Lentil (Lens culunaris L.). Communication in Soil Science and plant analysis 45: 2807-2818.

Singh VK, Naresh P, Biswas SK and Singh GP. 2010. Efficacy of fungicides for management of Wilt disease of lentil caused by Fusarium oxysporum f sp. lentis. Ann. of Pl. Protect. Sci.18: 411414.

Sugha SK, Kapoor SK and Singh BM. 1995. Management of chickpea wilt with fungicides. Indian Phytopath 48: 27-31.

Vasudeva RS and Srinivasan KV. 1952. Studies on the wilt diseases of lentil. Indian Phytopathology 5:23-32.

Vincent JM.1927. Distortion fungal hyphae in present of certain inhibitor. Nature 159: 850-853.

Citation:

Ram K and Singh R. 2021. Efficacy of different fungicides and biopesticides for the management of lentil wilt (Fusarium oxysporum f. sp. lentis). Journal of AgriSearch 8 (1):55-58 